American Journal of Environmental Sciences 6 (1): 50-56, 2010

ISSN 1553-345X

(C) 2010 Science Publications

\title{
Assessment of Pollution Hazards of Shallow Well Water in Abeokuta and Environs, Southwest, Nigeria
}

\author{
${ }^{1}$ E.O. Orebiyi, ${ }^{1}$ J.A. Awomeso, ${ }^{1}$ O.A. Idowu, ${ }^{1}$ O. Martins, \\ ${ }^{2}$ O. Oguntoke and ${ }^{2}$ A.M. Taiwo \\ ${ }^{1}$ Department of Water Resources Management and Agrometeorology, \\ University of Agriculture, P.O. Box 1074, Sapon Abeokuta, Nigeria \\ ${ }^{2}$ Department of Environmental Management and Toxicology, \\ University of Agriculture, P.O. Box 1074, Sapon Abeokuta, Nigeria
}

\begin{abstract}
Problem statement: Pollution of well water, either from point or non-point sources, has become a thing of health concern both in urban and rural areas. Approach: This study aim at assessing the pollution hazards of groundwater resource by sampling some shallow wells from urban and periurban area of Abeokuta. Collected samples were analyzed for water quality parameters using standard procedures. The parameters determined were: Static water level, color, turbidity, temperature, Electrical Conductivity (EC), pH, Total Dissolved Solids (TDS) Total Suspended Solids (TSS), Total Solids (TS), total hardness, cations \{potassium (K) sodium (Na), Calcium (Ca), magnesium (mg), Manganese $(\mathrm{Mn})$, iron $(\mathrm{Fe})\}$, anions $\left(\right.$ Chloride $\left(\mathrm{Cl}^{-}\right)$, Nitrate $\left(\mathrm{NO}_{3}\right)$, Sulphate $\left(\mathrm{SO}_{4}\right)$, Phosphate $\left.\left(\mathrm{PO}_{4}\right)\right\}$, heavy metals $\{$ lead $(\mathrm{Pb})$, Zinc $(\mathrm{Zn})$, Copper $(\mathrm{Cu})\}$ and microbiological parameters $\{$ Bacteria count and Total Coliform count (TC) \}. Results: Results were subjected to statistical evaluations using SPSS 15.0 for descriptive statistics and Analysis Of Variance (ANOVA). The mean values of TDS, TS, EC and $\mathrm{PO}_{4}$ were higher in well water collected from urban areas compared to peri-urban areas during wet season. It was also observed that during the dry season, TDS, TSS, TS, EC, $\mathrm{Mg}, \mathrm{Fe}, \mathrm{Cl}^{-}, \mathrm{PO}_{4}$ and total hardness were also higher in samples collected from urban areas relative to peri-urban well water samples. Conclusion: Water quality parameters such as $\mathrm{Fe}, \mathrm{Pb}, \mathrm{NO}_{3}, \mathrm{EC}$, Bacteria count and total coliform have mean values greater than World Health Organization maximum permissible standards for drinking water. Elevated values of these parameters are of great concern to public health when the water from these wells is consumed by people without treatment.
\end{abstract}

Key words: Water quality, urban, peri-urban, public health

\section{INTRODUCTION}

Safe water has been described as water that meets the National Standard for Drinking Water Quality for Nigeria (Federal Ministry of Water Resources, 2004). Access to safe drinking water is a prerequisite to poverty reduction and that access to safe drinking water prevents the spread of water-borne and sanitation-related diseases; however a large proportion of Nigerians still lack access to safe clean water. In Nigeria, $52 \%$ of the population does not have access to safe drinking water. Lack of access to safe water and adequate sanitation services especially in developing countries often results in the death of about two million infants annually (UNICEF, 2005; Cosgrove and Rijsberman, 2000; Gomez and Nakat,
2002). As a result of rapid expansion of cities and subsequent population explosion, the development of groundwater resources for potable use has increased substantially over the last decade especially in developing countries. Abeokuta is continually growing in human population and this has resulted in continuous increase in water consumption demand. The new Abeokuta water Scheme at Arakanga, Abeokuta, which supplies water to over six hundred thousand Abeokuta's residents, has a design capacity of 163 million $\mathrm{L} \mathrm{day}^{-1}$. Presently, the scheme produces 80 million $\mathrm{L} \mathrm{day}^{-1}$ leaving a shortfall of 40 million $\mathrm{L} \mathrm{day}^{-1}$ in the domestic water demand of Abeokuta and environs which has been estimated to be 120 million $\mathrm{L} \mathrm{day}^{-1}$. This situation has led to persistent water shortage in the city and its environs. To meet this huge shortfall in

Corresponding Author: Orebiyi Olabisi, Department of Water Resources Management and Agrometeorology, University of Agriculture, P.O. Box 1074, Sapon Abeokuta, Nigeria 
Am. J. Environ. Sci., 6 (1): 50-56, 2010

the daily water demand, shallow groundwater is being considered a complementary source. Groundwater is tapped at shallow depths for domestic uses through the construction of hand dug wells. However, while providing an alternative to the public water supply sources; most of the wells are often located too close to possible contamination sources.

Close relationship exists between groundwater quality and land use. Various land use activities can result in ground water contamination. Potential sources of groundwater pollution include solid waste landfills, on-site excreta disposal systems, cemetery and animal wastes resulting from human activities among others. In a solid waste landfill (open dumping or sanitary landfill), the organic and inorganic by-products resulting from the decomposition of wastes are leached out by the infiltration of rainfall. If leachate is released to the surrounding soil without proper collection and treatment, it could contaminate groundwater resources (Somjai and Suporn, 1993). Studies have shown that the leachate causes an increase in dissolved inorganic substances such as chloride, sulfate, bicarbonate, sodium and potassium of groundwater (Zanoni and Fungaroli, 1973; Kelly, 1976). Groundwater contamination can originate on the surface of the ground, above the water table, or below the water table. Where a contamination originates is a factor that can affect its actual impact on groundwater quality. In comparison with rivers, groundwater tends to move very slowly and with very little turbulence. Therefore once the contamination reaches the groundwater, dilution or dispersion normally takes a long time. The contaminants usually form a concentrated plume that flows along the same path as the groundwater. Among the factors that determine the size, form and rate of movement of contaminant plume are the amount and type of contaminant and the velocity of groundwater movement. Groundwater contaminants could be undetected for years until the supply is tapped for use. Substances that can contaminate groundwater can be divided into two basic categories: substances that occur naturally and substances produced by man's activities (USEPA, 1990). Naturally occurring substances include: minerals such as iron, calcium, magnesium, manganese, copper and selenium while anthropogenic substances are: Synthetic organic chemicals, hydrocarbons, pesticides, Polychlorinated Biphenyl (PCB), landfill leachates (liquids that have dipped through the landfill and carry dissolved substances like heavy metals, organic decomposition products), salts; bacteria and viruses. This study was carried out to assess the pollution hazards of shallow wells water in Abeokuta and its environs, Southwest,
Nigeria through determination of water quality parameters.

Description of shallow wells: If the groundwater is tapped over the first impermeable stratum, it is termed shallow well. If this stratum is near the surface, the water lying upon it has little protection from surface pollution. If deep, the surface water, as it sinks, has the impurities drained out of it by the thick layer of soil. Hand-dug wells are typical examples of shallow wells. A dug well may be $0.9-1.8 \mathrm{~m}$ in diameter and 4.5-10 $\mathrm{m}$ deep depending on where the water bearing formation or groundwater is encountered. In order to protect a dug well from contamination, watertight casing of concrete or brick set in cement, or large diameter close jointed piping is installed. The casing is usually carried up to form a platform 0.4-1.2 m high around the well mouth. A rounded or rectangular concrete slate is also used as a cover over the well, which is usually made to grower into a slot in the platform.

Study area: The study was carried out in urban and peri-urban areas of Abeokuta, the capital of Ogun State, Nigeria (Fig. 1). Abeokuta is in the sub-humid tropical region of southwestern Nigeria and it lies between latitude $7^{\circ} 5^{\prime \prime} \mathrm{N}-7^{\circ} 20^{\prime \prime} \mathrm{N}$ and longitude $3^{\circ} 17^{\prime} \mathrm{E}-3^{\circ} 27^{\prime \prime} \mathrm{E}$. It has a population of 605,451 (Projected from 1991 Census of 374,043 at 3.5 growth rate). Its geographical location makes it easily accessible from Lagos, the industrial capital of Nigeria and the nation's major seaport. The city covers a geographical area of $1,256 \mathrm{~km}^{2}$, which include Abeokuta South, Abeokuta North and part of Obafemi Owode and Odeda Local Government Areas of Ogun State.

\section{MATERIALS AND METHODS}

Peri-urban Areas are settlements found on the border of cities and towns and are in transition to be incorporated into urban areas. The communities in the peri-urban areas of Abeokuta where water samples from hand-dug wells were collected included: Banjoko, Adehun, Bode-Olude, Oke Ata, Osiele, Oloke, Kemta Idi Aba, Ijeun Lukosi, Obantoko, Camp and Adigbe. Majority of the people living in these parts of the city were farmers with a few population engaging in animal rearing on free-range system. Houses in these communities are sparsely located with about four to eight inhabitants per house. Vegetal growth is also peculiar in these areas. 


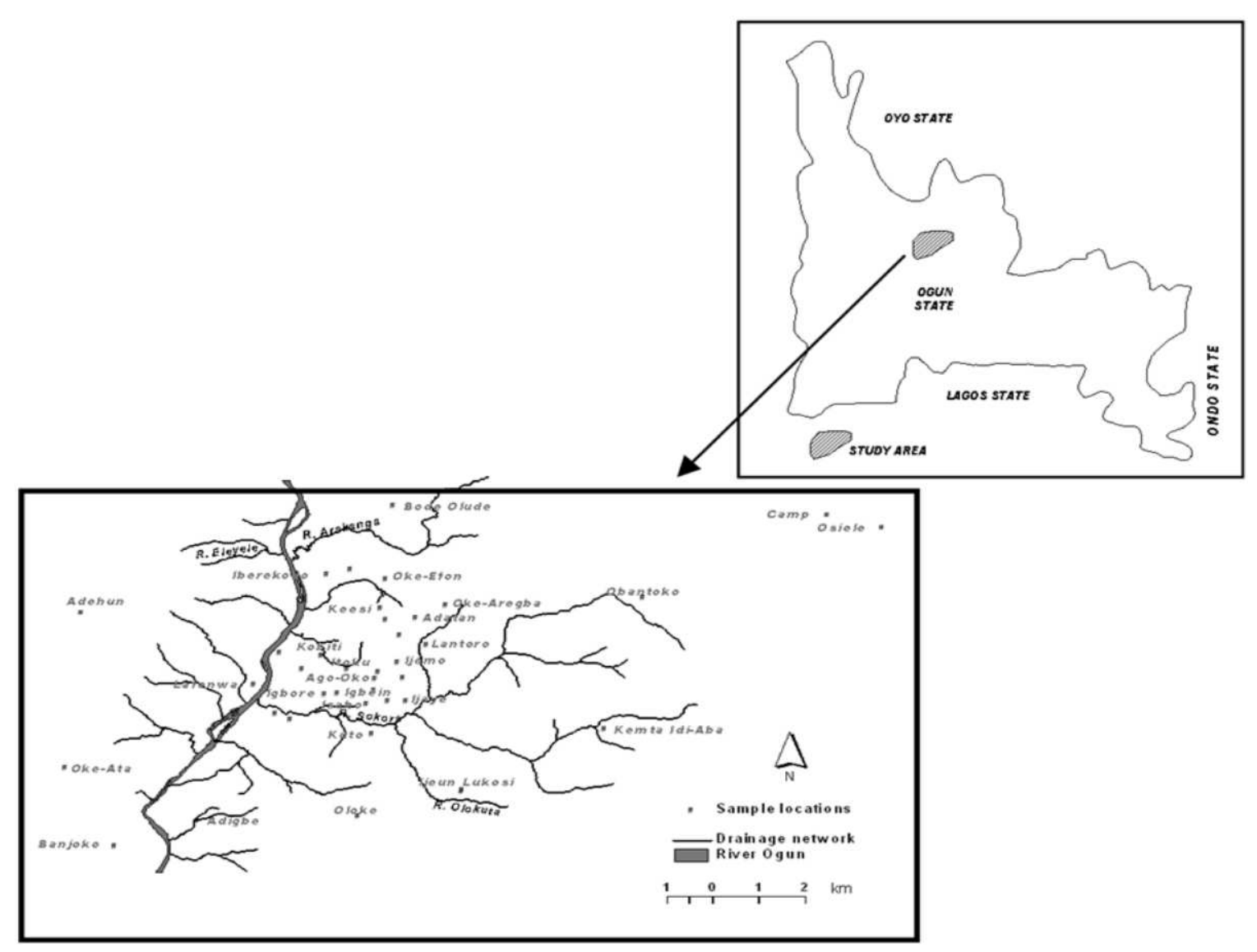

Fig.1: Map of study area showing drainage network and sample locations

Urban centers are considered as the continuous build-up areas of largest cities and towns. In the urban areas, water samples were collected from the following locations: Isabo, Ago-Oko, Ijeun, Ijaye, Ilogbo, OkeEjigbo, Ago-Oba, Lantoro, Ake, Adatan, Oke-Aregba, Totoro, Oke-Sokori, Lafenwa, Iberekodo, Keesi, ItaElega, Itoko, Oke-Efon, Igbein, Igbore, Ago-Oba, Kobiti and Itoku. Most of the people who live in these areas of Abeokuta are educated while some are not. The major activities in these areas are trading, textile making, artisans and transportation activities. Houses in these areas are densely populated with about six to twenty persons per house.

A total number of 76 shallow wells were investigated in Abeokuta and its environs. Fifty-four wells were sampled from urban areas while 22 wells were from peri-uban areas. The study covers both dry and wet seasons. The following parameters were analyzed using standard procedures (Clesceri, 1989): Color, turbidity, temperature, electrical conductivity, $\mathrm{pH}$, total dissolved solids, total suspended solids, total solids, total hardness, potassium, sodium, calcium, magnesium, manganese, iron, lead, zinc, copper, chloride, nitrate, sulphate, phosphate, Bacteria count and coliform count. Static water levels of the wells were also measured. $\mathrm{pH}$, conductivity and total dissolved soilds were measured with COMBO HI model $98130 \mathrm{pH} /$ Conductivity/TDS meter. Total hardness was determined by complexometric titration with standard EDTA as titrant in the presence of Eriochrome Black T indicator. Sodium and potassium were determined with flame photometer (Model PFP 7, JENWAY, UK). Other metals were analyzed by Atomic Absorption Spectrophotometric (AAS) method. TSS was determined gravimetrically while TS was determined by summing TDS and TSS together. Water temperature was measure by using mercury thermometer. Chloride was determined by using silver nitrate titration method as potassium chromate served as indicator (Vogel and Bassett, 1978). Color and turbidity were determined spectrophotometrically using UV/Visible spectrophotometer (HACH DR/4000, UK). Bacteria count and total coliform count were determined by staining and total viable cell count method. The static 
Am. J. Environ. Sci., 6 (1): 50-56, 2010

water level was measured with tape rule. Results were analyzed using SPSS version 15.0 package.

\section{RESULTS}

The mean values of groundwater parameters collected from fifty four shallow wells in urban areas are shown in Table 1 while that of peri-urban areas (twenty two wells) are depicted in Table 2. The wells sampled in the urban areas have concentrations of TDS, TSS, TS, Fe and Pb higher at wet season compared to dry season. For peri-urban samples, it was observed that parameters such as TSS, TDS and phosphate are higher during the wet season relative to dry season.

Table 1: Mean values of groundwater parameters determined in shallow wells of urban areas.

\begin{tabular}{|c|c|c|c|}
\hline Parameters & Mean \pm SD wet season & Mean \pm SD dry season & WHO standards \\
\hline SWL (m) & $2.85 \pm 1.27$ & $4.11 \pm 1.20$ & \\
\hline Color (TCU) & $6.39 \pm 2.98$ & $9.91 \pm 12.98$ & 15.0 \\
\hline Turbidity (NTU) & $4.16 \pm 2.20$ & $6.80 \pm 8.18$ & 5.0 \\
\hline Temperature $\left({ }^{\circ} \mathrm{C}\right)$ & $25.19 \pm 0.67$ & $28.26 \pm 0.48$ & \\
\hline $\mathrm{pH}$ & $6.73 \pm 0.30$ & $7.19 \pm 0.32$ & $6.5-8.5$ \\
\hline $\operatorname{TDS}\left(\mathrm{mg} \mathrm{L}^{-1}\right)$ & $402.72 \pm 117.44$ & $377.50 \pm 184.24$ & 500 \\
\hline $\mathrm{TSS}\left(\mathrm{mg} \mathrm{L}^{-1}\right)$ & $604.52 \pm 198.34$ & $228.57 \pm 141.31$ & \\
\hline $\mathrm{TS}\left(\mathrm{mg} \mathrm{L}^{-1}\right)$ & $604.52 \pm 198.13$ & $605.94 \pm 294.68$ & 2000 \\
\hline $\mathrm{EC}\left(\mu \mathrm{S} \mathrm{cm}^{-1}\right)$ & $865.37 \pm 242.19$ & $976.26 \pm 288.53$ & \\
\hline $\mathrm{Ca}\left(\mathrm{mg} \mathrm{L}^{-1}\right)$ & $23.17 \pm 9.77$ & $44.17 \pm 16.51$ & \\
\hline $\operatorname{Mg}\left(\mathrm{mg} \mathrm{L}^{-1}\right)$ & $7.09 \pm 3.57$ & $37.76 \pm 16.09$ & \\
\hline $\mathrm{Na}\left(\mathrm{mg} \mathrm{L}^{-1}\right)$ & $64.32 \pm 41.68$ & $51.44 \pm 34.73$ & 200 \\
\hline $\mathrm{K}\left(\mathrm{mg} \mathrm{L}^{-1}\right)$ & $29.50 \pm 23.73$ & $18.01 \pm 11.51$ & \\
\hline $\mathrm{Fe}\left(\mathrm{mg} \mathrm{L}^{-1}\right)$ & $0.37 \pm 0.65$ & $0.13 \pm 0.18$ & 0.30 \\
\hline $\mathrm{Cl}^{-}\left(\mathrm{mg} \mathrm{L}^{-1}\right)$ & $128.51 \pm 83.68$ & $213.39 \pm 118.70$ & 200 \\
\hline $\mathrm{NO}_{3}^{-}\left(\mathrm{mg} \mathrm{L}^{-1}\right)$ & $12.02 \pm 7.52$ & $12.00 \pm 7.16$ & 10.0 \\
\hline $\mathrm{SO}_{4}{ }^{2-}\left(\mathrm{mg} \mathrm{L}^{-1}\right)$ & $26.21 \pm 18.19$ & $22.18 \pm 14.67$ & 500 \\
\hline $\mathrm{PO}_{4}{ }^{3-}\left(\mathrm{mg} \mathrm{L}^{-1}\right)$ & $0.21 \pm 0.36$ & $0.07 \pm 0.21$ & \\
\hline $\mathrm{Pb}\left(\mathrm{mg} \mathrm{L}^{-1}\right)$ & $0.25 \pm 0.16$ & $0.01 \pm 0.02$ & 0.01 \\
\hline $\operatorname{Mn}\left(\mathrm{mg} \mathrm{L}^{-1}\right)$ & $0.02 \pm 0.07$ & $0.02 \pm 0.03$ & 0.50 \\
\hline $\mathrm{Zn}\left(\mathrm{mg} \mathrm{L}^{-1}\right)$ & $0.12 \pm 0.25$ & $0.05 \pm 0.04$ & 30.0 \\
\hline $\mathrm{Cu}\left(\mathrm{mg} \mathrm{L}^{-1}\right)$ & $0.06 \pm 0.13$ & $0.05 \pm 0.09$ & 2.0 \\
\hline Total hardness $\left(\mathrm{mg} \mathrm{L}^{-1}\right)$ & $30.26 \pm 11.90$ & $81.94 \pm 28.13$ & \\
\hline Bacteria count (cfu/100 mL) & $35.72 \pm 33.44$ & $25.45 \pm 25.93$ & 0.0 \\
\hline Coliform count ( $\left.\mathrm{cfu} \mathrm{mL}^{-1}\right)$ & $105.56 \pm 27.05$ & $91.60 \pm 32.23$ & 0.0 \\
\hline
\end{tabular}

SWL: Static Water Level

Table 2: Mean values of groundwater parameters determined in shallow wells from peri-urban areas

\begin{tabular}{|c|c|c|c|}
\hline Parameters & Mean \pm SD wet season & Mean \pm SD dry season & WHO standards \\
\hline SWL (m) & $3.62 \pm 1.47$ & $5.48 \pm 2.52$ & \\
\hline Color (TCU) & $7.73 \pm 4.0$ & $12.50 \pm 20.456$ & 15.0 \\
\hline Turbidity (NTU) & $4.58 \pm \pm 2.91$ & $8.75 \pm 17.93$ & 5.0 \\
\hline Temperature $\left({ }^{\circ} \mathrm{C}\right)$ & $25.27 \pm 0.77$ & $28.41 \pm 0.59$ & \\
\hline $\mathrm{pH}$ & $6.66 \pm 0.41$ & $6.94 \pm 0.48$ & $6.5-8.5$ \\
\hline TDS (mg L $\left.{ }^{-1}\right)$ & $263.68 \pm 150.06$ & $263.45 \pm 190.01$ & 500 \\
\hline $\operatorname{TSS}\left(\mathrm{mg} \mathrm{L}^{-1}\right)$ & $169.41 \pm 99.54$ & $138.96 \pm 100.76$ & \\
\hline TS & $433.09 \pm 238.49$ & $401.95 \pm 267.30$ & 2000 \\
\hline $\mathrm{EC}\left(\mu \mathrm{S} \mathrm{cm} \mathrm{cm}^{-1}\right)$ & $564.55 \pm 327.29$ & $551.91 \pm 387.52$ & \\
\hline $\mathrm{Ca}\left(\mathrm{mg} \mathrm{L}^{-1}\right)$ & $24.49 \pm 9.63$ & $31.41 \pm 15.20$ & \\
\hline $\operatorname{Mg}\left(\mathrm{mg} \mathrm{L}^{-1}\right)$ & $6.68 \pm 3.41$ & $28.05 \pm 21.05$ & \\
\hline $\mathrm{Na}\left(\mathrm{mg} \mathrm{L}^{-1}\right)$ & $51.51 \pm 23.17$ & $40.05 \pm 23.83$ & 200 \\
\hline $\mathrm{K}\left(\mathrm{mg} \mathrm{L}^{-1}\right)$ & $32.06 \pm 21.99$ & $15.44 \pm 9.48$ & \\
\hline $\mathrm{Fe}\left(\mathrm{mg} \mathrm{L}^{-1}\right)$ & $0.23 \pm 0.20$ & $0.22 \pm 0.18$ & 0.30 \\
\hline $\mathrm{Cl}^{-}\left(\mathrm{mg} \mathrm{L}^{-1}\right)$ & $130.68 \pm 71.38$ & $135.18 \pm 173.35$ & 200 \\
\hline $\mathrm{NO}_{3}^{-}\left(\mathrm{mg} \mathrm{L}^{-1}\right)$ & $10.69 \pm 5.82$ & $11.49 \pm 6.22$ & 10.0 \\
\hline $\mathrm{SO}_{4}^{2-}\left(\mathrm{mg} \mathrm{L}^{-1}\right)$ & $33.27 \pm 16.01$ & $22.59 \pm 15.01$ & 500 \\
\hline $\mathrm{PO}_{4}{ }^{3-}\left(\mathrm{mg} \mathrm{L}^{-1}\right)$ & $0.03 \pm 0.09$ & $0.14 \pm 0.16$ & \\
\hline $\mathrm{Pb}\left(\mathrm{mg} \mathrm{L}^{-1}\right)$ & $0.19 \pm 0.18$ & $0.04 \pm 0.07$ & 0.01 \\
\hline $\operatorname{Mn}\left(\mathrm{mg} \mathrm{L}^{-1}\right)$ & $0.02 \pm 0.44$ & $0.01 \pm 0.03$ & 0.50 \\
\hline $\mathrm{Zn}\left(\mathrm{mg} \mathrm{L}^{-1}\right)$ & $0.09 \pm 0.03$ & $0.04 \pm 0.02$ & 30.0 \\
\hline $\mathrm{Cu}\left(\mathrm{mg} \mathrm{L}^{-1}\right)$ & $0.07 \pm 0.13$ & $0.03 \pm 0.02$ & 2.0 \\
\hline Total hardness $\left(\mathrm{mg} \mathrm{L}^{-1}\right)$ & $31.17 \pm 12.20$ & $59.45 \pm 30.99$ & \\
\hline Bacteria count (cfu/100 mL) & $49.83 \pm 39.98$ & $15.42 \pm 19.54$ & 0.0 \\
\hline Coliform count $\left(\mathrm{cfu} \mathrm{mL} \mathrm{m}^{-1}\right)$ & $100.0 \pm 17.32$ & $91.00 \pm 43.57$ & 0.0 \\
\hline
\end{tabular}

SWL: Static Water Level 
Am. J. Environ. Sci., 6 (1): 50-56, 2010

In both areas, the static water level was lower during the dry season, due to lack of recharge by rainfall and draft in groundwater reserve as a result of continuous abstraction of groundwater by domestic users. Results shows the pattern of dominance of major cations based on the mean values to be $\mathrm{Na}>\mathrm{K}>\mathrm{Ca}>\mathrm{Mg}$ during wet season and $\mathrm{Na}>\mathrm{Ca}>\mathrm{Mg}>\mathrm{K}$ during the dry season in urban and peri-urban areas.

\section{DISCUSSION}

The seasonal values of color in both urban and peri-urban samples are within the 15.0 CTU WHO values permited in drinking water (World Health Organization, 1993). The value of turbidity was higher than WHO standard in dry season of both urban and peri-urban groundwater. High turbidity values in these wells are indications of high-suspended materials, algae and aquatic microscopic organisms (Clesceri, 1989).

The high turbidity at dry season may have also resulted into high color values respectively. The water temperature, which is generally less than $29^{\circ} \mathrm{C}$, may affect the chemistry of the groundwater as well as metals toxicity (Awofolu et al., 2007). $\mathrm{pH}$ values of the well samples are in the normal range of WHO standard in drinking water. However, lower $\mathrm{pH}$ at wet season may result from deposition of $\mathrm{CO}_{2}$ during precipitation. TDS and TS values fall below the international permissible standard in drinking water (World Health Organization, 1993). But, the high value of TSS in these wells is of health concern. Normally, TS value in water should be in the range of $25-80 \mathrm{mg} \mathrm{L}^{-1}$ (Robert, 1978). A positive significant correlation between TSS and turbidity has been established (Bertram and Balance, 1998). Invariably, high TSS indicates high load of both organic and inorganic materials in the water. Electrical conductivity is a measure of the ions or salinity. It has a mean value between $551.91 \pm 387.52$ and $976.26 \pm 288.53 \mu \mathrm{S} \mathrm{cm}^{-1}$ (Table 1 and 2) and is a reflection of high dissolved solids. Based on groundwater classification (Freeze and Cherry, 1979), the samples fall within brackish water. High conductivity indicates high $\mathrm{Na}$ and $\mathrm{K}$ salts, which was evident in the values obtained from these metals (Adediji and Ajibade, 2005). Total hardness mean results are below $70 \mathrm{mg} \mathrm{L}^{-1}$ in all the samples (Table 2) except the dry season value in well water from urban areas (Table 2); therefore the groundwater could be described as soft (Environment Canada, 1977).

Calcium concentration is within the $10-100 \mathrm{mg} \mathrm{L}^{-1}$ permissible in potable groundwater (Adediji and Ajibade, 2005; Walker, 1973). Calcium has no health effects on human. Magnesium concentrations in the sampled well water also fall within $1.0-40 \mathrm{mg} \mathrm{L}^{-1}$ normal range values in potable groundwater (Adediji and Ajibade, 2005). The value of $\mathrm{Na}$ is greater than that of $\mathrm{K}$, which was in line with the observation that, concentration of $\mathrm{K}$ should normally be around one-tenth of sodium concentration and less than $10.0 \mathrm{mg} \mathrm{L}^{-1}$ for potable groundwater (Adediji and Ajibade, 2005). However, the least value of potassium recorded in this study is found in the peri-urban wells with a mean value of $15.44 \pm 9.48 \mathrm{mg} \mathrm{L}^{-1}$ (Table 2). Except for the mean value of iron $\left(0.37 \pm 0.65 \mathrm{mg} \mathrm{L}^{-1}\right)$ observed in the well water of urban areas (Table 1), the rest values fall bellow WHO standard of $0.30 \mathrm{mg} \mathrm{L}^{-1}$ in potable water. High iron concentration in water could impart taste, discoloration, deposits and turbidity (World Health Organization, 1971). Pb concentration was also high in the well samples, greater than WHO standard of $0.01 \mathrm{mg} \mathrm{L}^{-1}$. $\mathrm{Pb}$ has being classified as potentially hazardous and toxic to most forms of life (USEPA, 1986). It also causes a number of ailments in humans such as chronic neurological disorders in fetuses and children. Manganese, zinc and copper mean concentrations are within the WHO limits permitted in potable water. The higher values of most parameters especially the metals in urban wells (Table 1) could be attributed to the high urban run-off (USEPA, 1986) and the activities going on around the areas (textile making, transportation).

Chloride and sulphate mean concentrations are within the WHO minimum permissible limits of 250 and $500 \quad \mathrm{mg} \mathrm{L}^{-1}$ respectively. High chloride concentration in groundwater may indicate pollutions by sewage, industrial wastes or saline water intrusions (Bertram and Balance, 1998). Both chloride and sulphate have no health implication on human but at high concentrations chloride could impart taste in water while sulphate could cause gastrointestinal irritation (World Health Organization, 1971). The nitrate values were higher than WHO standard of $10.0 \mathrm{mg} \mathrm{L}^{-1}$ in drinking water. This has a lot of health implication especially on the growing infants and pregnant women (Adekunle et al., 2007). However, the high nitrate values in all the aquifers sampled are of health-concern especially to growing infants as it causes methemoglobinemia. The symptoms of methemoglobinemia are paleness, bluish mucous membranes, digestive and respiratory problems (McCasland et al., 2007). World Health Organization has no standard for phosphate, however, a save limit of phosphate concentration in uncontaminated water in the range of $0.01-0.03 \mathrm{mg} \mathrm{L}^{-1}$ has been established 
(Izonfuo and Bariweni, 2001). With this value, the mean phosphate concentrations in the wells from urban areas exceeded this limit (Table 1) while in the periurban wells; mean phosphate value obtained in the wet season is within the limit. But the mean phosphate concentration of the wells during dry season is greater than the standard (Table 2).

The presence of bacteria and total coliform in the well water indicate contamination by human or animal wastes. These pathogens may pose a special health risk for infants, young children and people with severely compromised immune systems (USEPA, 2002). WHO has recommended a zero value of bacteria and total coliform count in drinking water. The mean values of bacteria count between $15.42 \pm 19.54$ and $49.83 \pm 39.98 \mathrm{cfu} / 100 \mathrm{~mL}$ (Table 1 ) is extremely high in groundwater to be used for drinking purposes. Mean result of total coliform per $\mathrm{mL}$ was also extremely high, indicating the pollution of the wells by faecal matters.

\section{CONCLUSION}

The high values of some physico-chemical (color, turbidity, nitrate, iron, manganese, lead, total suspended solids, phosphate) and microbiological parameters (bacteria and total coliform) in the study wells higher than the recommended limits is an indication of pollution hazards. This however, in return has implications on human health as these wells are the main source of drinking water supply to the residents. It was also observed from this study that most of the water parameters were higher in wells water collected from urban areas relative to peri-urban wells. Generally, the mean results of most parameters were higher at dry season than rainy or wet season.

Recommendation: This study therefore recommended that wells should not be dug near contamination sources and also that, the wells should always be properly lined and covered. Moreover, water from the well should be treated before consumed. Further research works should be conducted on the sampled wells for proper monitoring.

\section{REFERENCES}

Adediji, A. and L.T. Ajibade, 2005. Quality of well water in Ede Area Southwestern Nigeria. J. Hum. Ecol., 17: 223-228. JHE-17-3-223-228-2005-1229Adediji-A.pdf
Adekunle, I.M., M.T. Adetunji, A.M. Gbadebo and O.B. Banjoko, 2007. Assessment of groundwater quality in a typical rural settlement in southwest, Nigeria. Int. J. Environ. Public Health, 4: 307-318. DOI: 10.3390/ijerph200704040007

Awofolu, O.R., R. Duplessis and I. Rampedi, 2007. Influence of discharge effluent on water quality of surface water utilized for agricultural purposes. Afr. J. Biotechnol., 6: 2251-2258. www.academicjournals.org/AJB/.../pdf2007

Bertram, J. and R. Balance, 1998. Water Quality Monitoring: A Practical Guide to the Design and Implementation of Freshwater Quality Studies and Monitoring Programmes. 1st Edn., Taylor and Francis, USA., ISBN: 0419223207, pp: 400.

Clesceri, L.S., 1989. Standard Methods for the Examination of Water and Wastewater. 17th Edn., American Public Health Association, Washington, DC., USA., ISBN: 13: 978-0875531618, pp: 1624.

Cosgrove, W.J. and F.R. Rijsberman, 2000. World Water Vision: Making Water Everybody's Business. Earthscan Publication Ltd., UK., ISBN: 185383730X, pp: 108.

Environment Canada, 1977. Surface Water Quality in Canada: An Overview. Inland Waters Directorate, Water Quality Branch, Canada. http://catalogue.nla.gov.au/Record/2503379

Federal Ministry of Water Resources, 2004. National rural water supply and sanitation: A strategic framework. Department of Water Supply and Quality Control, Abuja, pp: 48.

Freeze, R.A. and J.A. Cherry, 1979. Groundwater. 1st Edn., Prentice Hall Inc. Englewood Cliffs, New York, USA., ISBN: 0133653129, pp: 604.

Gomez, J.D. and A.C. Nakat, 2002. Community participation in water and sanitation. Water Int., 27: 343-353. DOI: 10.1080/02508060208687014

Izonfuo, L.W.A. and P.A. Bariweni, 2001. The effect of urban run-off water and human activities on some physico-chemical parameters of the epie creek of in the Niger Delta. J. Applied Sci. Environ. Manage., 5: 47-55.

http://www.bioline.org.br/abstract?id=ja01008\&lan $\mathrm{g}=\mathrm{en}$

Kelly, W., 1976. Groundwater pollution near a landfill. J. Environ. Eng. Divis. Am. Soc. Eng., 102: 1189-1199.

McCasland, M., N.M. Trautmann, R.J. Robert and K.S. Porter, 2007. Nitrate: Health effects in drinking water. http://psep.cce.cornell.edu/factsslides-self/facts/nit-heef-grw85.aspx

Robert, R.J., 1978. Fish Pathology. 2nd Edn., BailliereTindall, London, ISBN: 10-0702013145, pp: 360. 
Somjai, K. and K.T.I. Suporn, 1993. Monitoring and evaluation of shallow well water quality near a waste disposal site. Environ. Int., 19: 579-587.

USEPA., 1986. Quality criteria for water. United States Environmental Protection Agency, 20460 USEPA40015-86.

http://www.epa.gov/waterscience/criteria/library/g oldbook.pdf

USEPA., 1990. Citizen's Guide to Groundwater Protection. United States Environmental Protection Agency, 440/6-90-004.

http://www.epa.gov/safewater/sourcewater/pubs/cit guid.pdf

USEPA., 2002. National standards for drinking water. United States Environmental Protection Agency 816-F-02-013.

www.ehso.com/ehshome/DrWater/drinkingwaterep astds.php

UNICEF., 2005. National Rural water supply and Sanitation investment programme. Final draft, pp: 1.
Vogel, A.I. and J. Bassett, 1978. Textbook of Inorganic Analysis. 4th Edn., Longman, London, ISBN: 10: 0582463211, pp: 962.

Walker, W.H., 1973. Where have all the toxic chemical gone? Groundwater, 11: 11-20. DOI: $10.1111 / \mathrm{j} .1745-6584$

World Health Organization, 1971. Drinking Water Quality. 3rd Edn., Geneva. pp: 15-157.

World Health Organization, 1993. Guidelines for Drinking-Water Quality (Vol. 1). 2nd Edn., World Health Organization (WHO), Geneva, ISBN: 10: 9241545143, pp: 36.

Zanoni, A.E. and A. A. Fungaroli, 1973. Potential for ground water pollution from the land disposal of solid wastes. Crit. Rev. Environ. Sci. Technol., 3: 225-260. DOI: 10.1080/10643387309381603 